\title{
Model of Islamic Social Entrepreneurship: A Study on Successful Muslim Social Entrepreneur in Malaysia
}

\author{
Mohd Adib Boulven ${ }^{1}$, S. Abdullah ${ }^{1}$, Azizan Bahari ${ }^{1}$, A. J. Ramli', N. S. Hussin ${ }^{1}$, Jamsari Jamaluddin $^{1}$, and Z. Ahmad ${ }^{2}$ \\ ${ }^{1}$ School of Human Development and Technocomunication, Universiti Malaysia Perlis, Perlis, Malaysia \\ ${ }^{2}$ Institute Pendidikan Guru Malaysia Kampus Perlis, Perlis, Malaysia
}

\begin{abstract}
Since research effort in the area is minimal, there is a clear need to examine the practice of Islamic social entrepreneurship among successful Muslim social entrepreneurs in Malaysia. One such practice is to organize charitable activities to benefit the community through the gains made from entrepreneurial activities that are based on social mission and vision. The research problem is lacking of model on Islamic social entrepreneurship. The main objective of this paper is to develop a Model of Islamic Social Entrepreneurship based on successful Muslim social entrepreneur in Malaysia. The research method used in this study is literature review, content analysis, and interview with 14 participants constituting nine successful Muslim social entrepreneurs and five experts with religious academic backgrounds participated in the study. The research finding shows that model of Islamic social entrepreneurship is the major contribution of the study which could serve as guidelines for successful Muslim social entrepreneurs, particularly young entrepreneurs.
\end{abstract}

\section{Introduction}

Social entrepreneurship is an emerging area of research that examines business that is significantly influenced by entrepreneur's society's motives instead of being purely economically driven [1]. Social entrepreneurship is one of the branches of the economy that can alleviation of poverty and able to improve the country's economic status, from other perspectives such as charity and philanthophy as well as social services [2-3]. To seek for the lawful income is obligatory according to the Islamic view and work in the field of business entrepreneurship and make the essentials good for Muslims is obligatory (fardu kifayah) (Mohamad Mustafa, 2002). The concept of social entrepreneurship has been rapidly emerging in the private, public and nonprofit sectors over the last few years, and interest in social entrepreneurship continues to grow [4]. Social entrepreneurship has become a global phenomenon that impacts the society by employing innovative approaches to solve social problems [5].

Based on current economic conditions, social entrepreneurial activities is very important to reduce social problem especially in developing countries such a Malaysia [6]. Among the initial steps recommended by the Malaysian government is the collaboration between institutions of high potential from various government and private agencies need to adopt the concept of social entrepreneurship to the world of entrepreneurship in the field of research as a whole to help entrepreneurs develop a range of products and services with low prices and quality [6-7].

Social entrepreneurship has become a new phenomenon in a country in order to reduce social problems, eradicate poverty communities and to build up the good relationship between entrepreneurs and society [8-9]. According to figures from the famous corporate entrepreneur Muhammad Ali Hashim (2013), states that in Malaysia it is time for the Muslim entrepreneurs to implement the Islamic social entrepreneurship in the current practice of the concept of jihad business or jihad economy through Islamic social entrepreneurship and Islamic business entrepreneurship. Entrepreneurs are among the individuals and groups that are often discussed in the al-Qur'an, especially in a business context. Social entrepreneurs are entrepreneurs who have entrepreneurial activity in a business and have managed not to get a profit as a result of the activities. The main objective is to seek the pleasure and blessing of Allah SWT in this world and the hereafter [10].

Islamic social entrepreneurship is not foreign to Islam because this is part of business, entrepreneur and economic. Since the advent of Islam, Islamic social entrepreneurship has played a vital role in its spread. Islam has reached many parts of the world. The study based on Islamic social entrepreneurship from the social entrepreneurial activity is still new and lacking, especially in the Islamic perspective [3, 10-13]. As we all know that Islam is a monotheistic religion which is complete and perfect for all Muslims because it covers all aspects of the life of this world and the hereafter. Allah SWT says in the holy Qur'an: 
"Allah hath permitted exchange and forbidden usury" (Surah AlBaqarah, 2:275)

"This day, those who disbelieved have given up all hope of your religion; so fear them not, but fear Me. This day, I have perfected your religion for you, completed My favour upon you, and have chosen for you Islam as your religion. But as for him who is forced by severe hunger, with no inclination to sin (such can eat these above mentioned animals), then surely, Allah is Oft-Forgiving, Most Merciful." (Surah Al-Maidah, 5: 3)

Perfection of Islam not just includes religious aspects, but also the best life procedures outlined by Allah SWT. Al-Qur'an and al-Hadith is the main source of reference and complete guideline to the best human life. In addition, people are supplied with common sense to be used to achieve the purpose of life and closer to their Creator.

Based on the word of Allah which means: -

"Who is he that will lend to Allah a goodly loan so that He may multiple it to him many times And it is Allah that decreases or increase (your provisio), and unto Him you shall return." (Surah Al-Baqarah, 2: 245)

According to Ibnu Kathir, Allah encourages His servants to spend in His cause. Allah mentioned this same Ayah in several other parts of His Glorious Qur'an. The Hadith that mentions that Allah descends (every night down on the nearest heaven to us when the last third of the night remains) states that Allah says: Who would give a loan to He Who is neither poor nor unjust.

"By no means shall you attain Al-Birr, unless you spend of that which you love; and whatever of good you spend, Allah knows it well." (Surah Ali-Imran, 3:92)
Therefore, the main objectives of this study are: -

i. To develop model of Islamic social entrepreneurship among successful Muslim social entrepreneur in Malaysia.

\section{Research Methodology}

A qualitative approach is relevant to this study as it enables researchers to generate thick description of the social actors in their natural setting [14]. The study was conducted based on the methodology epistemology, content analysis and interviews. This study is also based on existing models and theories from previous studies. Comparative analysis approach was used to look at the elements from previous studies. As shown in Fig. 1. This study consists of two phases. The first phase is to analyze the previous models of social entrepreneurship through literature review, content analysis and comparative analysis. The second phase is to develop a model of Islamic social entrepreneurship according to Islamic perspective. The method used for second phase is interview. Interviewing participants was the primary method of data collection in this study. A semi structured interview involving 14 participants constituting nine successful Muslim social entrepreneurs and five experts with religious academic backgrounds participated in the study. The strength and advantage of a semi structured interview is that the interviewer can seek clarification and elaboration of the interviewees' responses and thus encourage further discussion on a particular topic.

Participants were identified through the purposeful sampling technique. We approached nine successful Muslim social entrepreneurs (Inang Suri Enterprise, Former CEO of Johor Corporation, Red Profile Sdn Bhd, Mohd Maliki Bin Endut Enterprise, Colours of Asia Sdn Bhd Group of Companies, Ameqin Sepakat, Prowheels (M) Sdn Bhd, Goncarian Enterprise, and IdSoft Enterprise) and five experts with religious academic backgrounds (Dean of Islamic Business School Universiti Utara Malaysia, Professor in Management and Entrepreneurship Universiti Malaysia Kelantan, two senior lecturers in Islamic Business School, and Religious Officer at Islamic Centre UUM. The data was analysed using thematic analysis within the constructionist paradigm. 


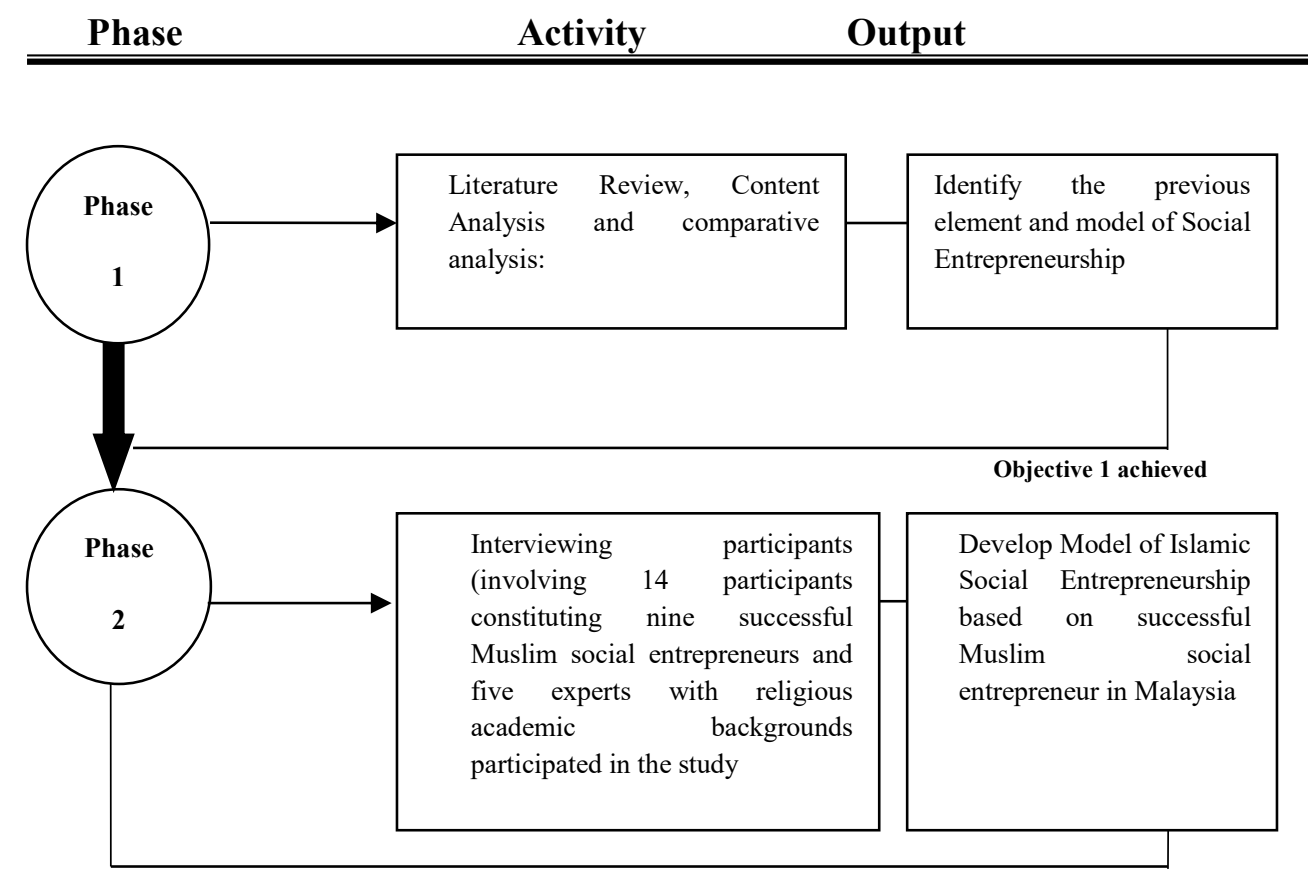

Objective 2 achieved

Fig. 1. Phase Analysis and Develop Model of Islamic Social Entrepreneurship

\section{Finding and Discussion}

All of these elements got from interview analysis, most

\begin{tabular}{|c|c|c|c|c|c|c|}
\hline \multicolumn{3}{|c|}{ Elements } & \multicolumn{4}{|c|}{$\begin{array}{l}\text { Participants } \\
(1,2,3,4,5,6,7,8,9,10,11,12,13,14)\end{array}$} \\
\hline \multicolumn{3}{|c|}{ 1. To seek pleasure of Allah s.w.t in the world and hereafter } & 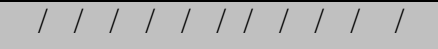 & 1 & & I \\
\hline \multicolumn{2}{|c|}{$\begin{array}{r}\text { 2. Conc } \\
\text { i. } \\
\text { ii. } \\
\text { iii. } \\
\text { iv. } \\
\text { v. } \\
\text { vi. } \\
\text { vii. } \\
\text { viii. } \\
\text { ix. } \\
\mathbf{x} \text {. } \\
\text { xi. } \\
\text { xii. }\end{array}$} & $\begin{array}{l}\text { of Islamic Social Entrepreneurship } \\
\text { Concept of Amar maa'ruf wa nahi munkar } \\
\text { Concept of Welfare } \\
\text { Concept of Fairness } \\
\text { Concept of al-Falah (success in world and the } \\
\text { hereafter) } \\
\text { Concept of Developing and improving of Social } \\
\text { Value providers } \\
\text { Concept of Khalifah } \\
\text { Concept of Charity } \\
\text { Concept of Waqf, hibah and zakat } \\
\text { Concept of Justice and balance } \\
\text { Concept of Welfare and social security } \\
\text { Concept of Jihad economy } \\
\text { Concept of Prayer and attending to Masjid. }\end{array}$ & $\begin{array}{lllllllllll}1 & 1 & 1 & 1 & 1 & 1 & 1 & 1 & 1 & 1 & 1 \\
1 & 1 & 1 & 1 & 1 & 1 & 1 & 1 & 1 & 1 & 1 \\
1 & 1 & 1 & 1 & 1 & 1 & 1 & 1 & 1 & 1 & 1 \\
1 & 1 & 1 & 1 & 1 & 1 & 1 & 1 & 1 & 1 & 1 \\
1 & 1 & 1 & 1 & 1 & 1 & 1 & 1 & 1 & 1 & 1 \\
1 & 1 & 1 & 1 & 1 & 1 & 1 & 1 & 1 & 1 & 1 \\
1 & 1 & 1 & 1 & 1 & 1 & 1 & 1 & 1 & 1 & 1 \\
1 & 1 & 1 & 1 & 1 & 1 & 1 & 1 & 1 & 1 & 1 \\
1 & 1 & 1 & 1 & 1 & 1 & 1 & 1 & 1 & 1 & 1 \\
1 & 1 & 1 & 1 & 1 & 1 & 1 & 1 & 1 & 1 & 1 \\
1 & 1 & 1 & 1 & 1 & 1 & 1 & 1 & 1 & 1 & 1 \\
1 & 1 & 1 & 1 & 1 & 1 & 1 & 1 & 1 & 1 & 1 \\
1 & 1 & 1 & 1 & 1 & 1 & 1 & 1 & 1 & 1 & 1 \\
1 & 1 & 1 & 1 & 1 & 1 & 1 & 1 & 1 & 1 & 1 \\
1 & 1 & 1 & 1 & 1 & 1 & 1 & 1 & 1 & 1 & 1\end{array}$ & 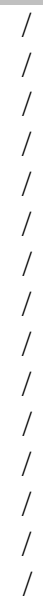 & $\begin{array}{l}1 \\
1\end{array}$ & $\begin{array}{l}1 \\
1 \\
1 \\
1 \\
1 \\
1 \\
1 \\
1 \\
1 \\
1 \\
1 \\
1 \\
1 \\
1 \\
1\end{array}$ \\
\hline \multicolumn{2}{|r|}{ Basic } & $\begin{array}{l}\text { lement of Muslim social entrepreneur } \\
\text { Iman } \\
\text { Taqwa } \\
\text { Ihsan } \\
\text { Sifat Mahmudah } \\
\text { i. Taubat } \\
\text { ii. Ikhlas } \\
\text { iii. Khauf } \\
\text { iv. Zuhud } \\
\text { v. Sabar } \\
\text { vi. Syukur } \\
\text { vii. Tawakal } \\
\end{array}$ & $\begin{array}{lllllllllll}1 & 1 & 1 & 1 & 1 & 1 & 1 & 1 & 1 & 1 & 1 \\
1 & 1 & 1 & 1 & 1 & 1 & 1 & 1 & 1 & 1 & 1 \\
1 & 1 & 1 & 1 & 1 & 1 & 1 & 1 & 1 & 1 & 1 \\
1 & 1 & 1 & 1 & 1 & 1 & 1 & 1 & 1 & 1 & 1 \\
1 & 1 & 1 & 1 & 1 & 1 & 1 & 1 & 1 & 1 & 1 \\
1 & 1 & 1 & 1 & 1 & 1 & 1 & 1 & 1 & 1 & 1 \\
1 & 1 & 1 & 1 & 1 & 1 & 1 & 1 & 1 & 1 & 1 \\
1 & 1 & 1 & 1 & 1 & 1 & 1 & 1 & 1 & 1 & 1 \\
1 & 1 & 1 & 1 & 1 & 1 & 1 & 1 & 1 & 1 & 1 \\
1 & 1 & 1 & 1 & 1 & 1 & 1 & 1 & 1 & 1 & 1 \\
1 & 1 & 1 & 1 & 1 & 1 & 1 & 1 & 1 & 1 & 1 \\
1 & 1 & 1 & 1 & 1 & 1 & 1 & 1 & 1 & 1 & 1 \\
\end{array}$ & $\begin{array}{l}1 \\
1 \\
1 \\
1 \\
1 \\
1 \\
1 \\
1 \\
1 \\
1 \\
1 \\
1\end{array}$ & 1 & $\begin{array}{l}1 \\
1 \\
1 \\
1 \\
1 \\
1 \\
1 \\
1 \\
1 \\
1 \\
1 \\
1 \\
1\end{array}$ \\
\hline
\end{tabular}

of participants agree that these elements must have in model of Islamic social entrepreneurship. 


\section{viii. Mahabbah \\ ix. Redha \\ x. Zikrul Maut}

4. Element of al-Maqasid al-Syariah. These are the preservation of:
i. Religion (deen)
ii. Life (nafs)
iii. Lineage (nasl)
iv. Intellect ('aql)
v. Property/ wealth (mal)

Source: From Interview Result

\subsection{Islamic Social Entrepreneurship based on Islamic perspective}

The concept of Islamic social entrepreneurship must refer the primary source in Islamic religion which is alQur'an and al-Hadith and must follow objective of the Shariah or al-Maqasid as-Shari'ah (preserve religion, life, intellectual, lineage, and property) in order to achieve the concept of al-Falah as stated in Fig. 2.
Besides, it must fulfil basic requirement to help people in solving the social problem [10]. According to Habibollah et al. [15], religious Waqf has been able in distribution of wealth in society and using finance and property in the line well-meaning humanitarian to develop opportunities and access vulnerable to the main infrastructure development. The tradition of the Prophet Muhammad: "Allah S.W.T. love the people whom help the poor and needy mankind".

The Concept of Social Entrepreneurship based on Islamic perspective (al-Qur'an,

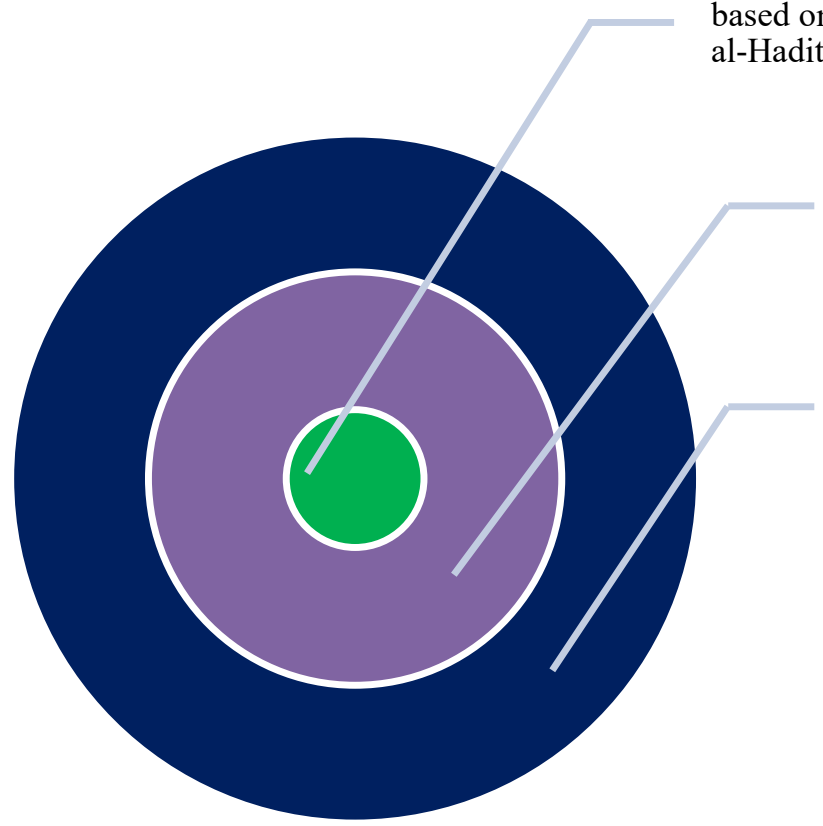

Research on Social Entrepreneurship based on model and concept.

Research about Social

Entrepreneurship in general.

Fig. 1.The Concept of Islamic social entrepreneurship 


\subsection{Model of Islamic Social Entrepreneurship}

Fig. 2 shows the model of Islamic social entrepreneurship based on interview analysis.

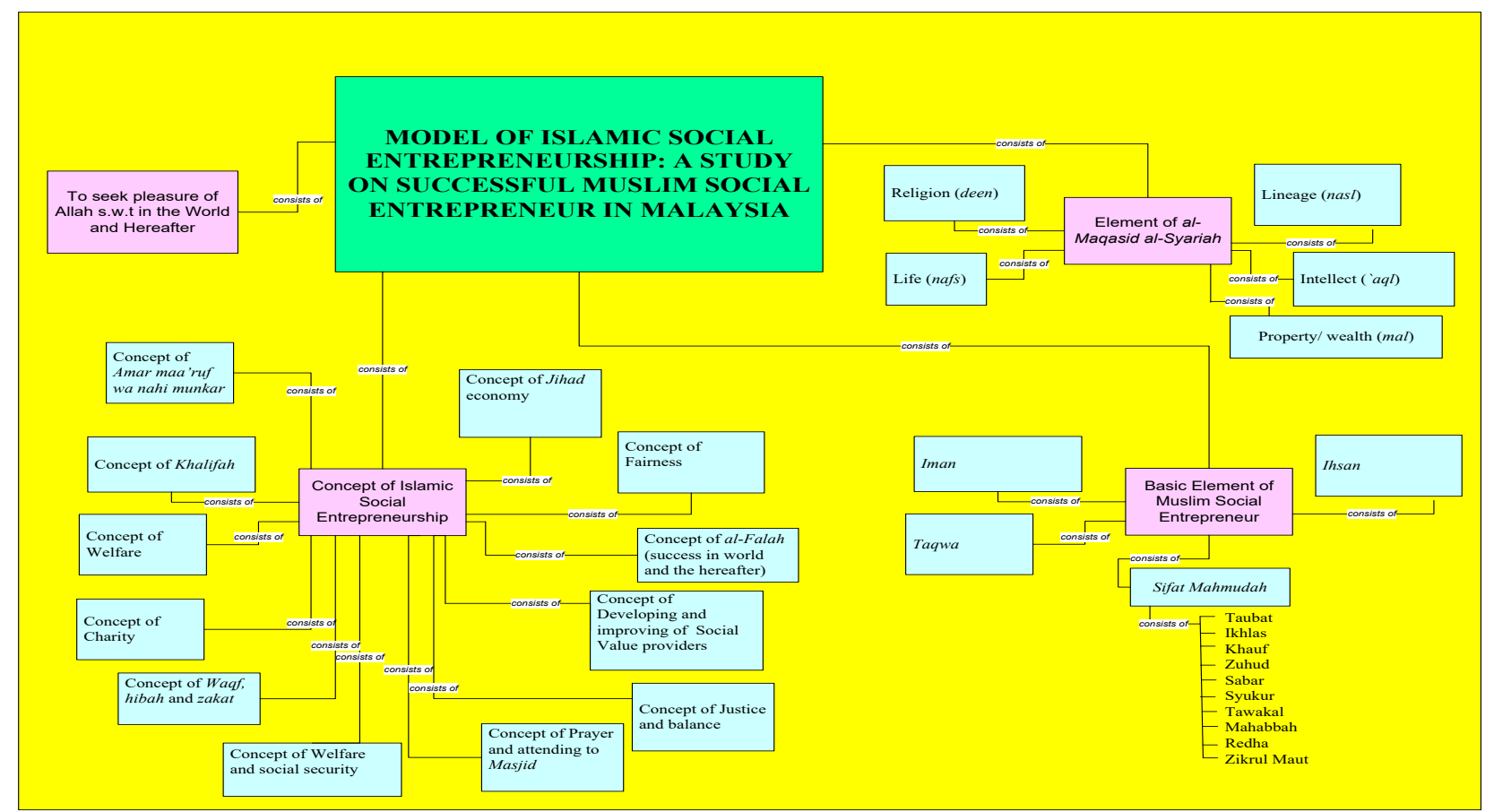

Fig. 2. Model of Islamic social entrepreneurship on successful Muslim social entrepreneur in Malaysia

\section{Conclusion}

In conclusion, this paper is an attempt to develop a model of Islamic social entrepreneurship on successful Muslim social entrepreneur. This study is based on the Al-Quran and As-Sunnah and need to implement the Maqasid Shari'ah (preserve religion, life, intellectual, lineage, and property) in to the real practices in order to achieve al-Falah (seek the pleasure of Allah s.w.t in this world and hereafter).

By developing this model it will not only helps successful Muslim social entrepreneur to implement the Islamic Social entrepreneurship in Malaysia but it can also be a guide to the new social entrepreneurs to learn and practice. Moreover, findings from the participants has shown that majority of the experts and Muslim social entrepreneurs agreed and perceived the elements in Model of Islamic social entrepreneurship useful and helpful to the Muslim social entrepreneur to implement the Islamic social entrepreneurship; help to seek the pleasure of Allah SWT; help to increase the activity of Islamic social entrepreneurship in Malaysia; help to increase the awareness of Muslim social entrepreneur; and help to reduce the social problems among society in Malaysia.

In addition, this study is very important to increase the economy growth for nation. Therefore, this study hopes that various parties to participate and take initiatives to increase the self-knowledge to help in eradication of social problems through Islamic social entrepreneurship. Besides, it can be additional reading materials in the collection of studies and research on the
Islamic perspective. Perhaps, this study also will contribute in a better understanding on the concept of Islamic social entrepreneurship. For future work, other researchers could expand the knowledge on Islamic social entrepreneurship from this study.

\section{Acknowledgement}

The author would like to thank to Universiti Malaysia Perlis (UniMAP) (http://www.unimap.edu.my) and the Ministry of Education Malaysia (http://www.moe.gov.my) for sponsoring this study.

\section{References}

1. J. Almarri, J. Meewella, T. Mainela, Social Entrepreneurship and Islamic Philanthropy. International conference on Excellence in Business. Shariah United Arab Emirates (2012)

2. Saifuddin Abdullah. (2012, 6 Ogos). "Keusahawanan Sosial Basmi Kemiskinan”. Akhbar Sinar Harian.

3. Suhaili Sarif. (2016). Social entrepreneurship through an Islamic institution: the Malaysian Zakat experience. Dalam al-Azmi Bakar, Zakaria Mat Yusof, Desa Mat Rabi, Umihani Awang, Rohaizal 
Umar, Baharudin Mohamad, Muhammad Yusry Che Dah, Ngeow Yeok Meng, Faezah Kassim, Ponmalar N. Alagappar, Faridah Che Husain, Zamre Abu Hassan dan Wendy Yee Mei Tien (ed.), Social entrepreneurship and community engagement: Transforming societies. Selangor: Social Institute of Malaysia (ISM).

4. Johnson, S. (2000), "Literature review on social entrepreneurship", available at:www.bus.ualberta.ca/ccse/Publications/P ublications/Lit._Review_SE_November_20 00.rtf (accessed February 20, 2011).

5. Robinson, J.A., Mair, J. and Hockerts, K., (Eds) (2009), International Perspectives of Social Entrepreneurship, Palgrave, London.

6. Saifuddin Abdullah. (2009, 29 Julai). "Keusahawanan Sosial Dalam Penyelidikan”. Akhbar Utusan Malaysia.

7. Mohd Adib Abd Muin, Shuhairimi Abdullah, Azizan Bahar, Journal of Human Development and Communication (JoHDeC) 4, 21-36 (2015)

8. J.T. Zietlow, Nonprofit Management and Leadership 13 (1), 85-90 (2002)

9. Mohd Adib Abd Muin, Azizi Abu Bakar, Shuhairimi Abdullah, Prosiding: International Conference on Business Innovation, Entrepreneurship and Engineering 2013, 386-399 (2013)

10. Mohd Adib Abd Muin, Shuhairimi Abdullah, Muhammad Fakhirin Che Majid, (2014). Pengurusan Keusahawanan Sosial Islam: Model Amalan Usahawan Berjaya Dalam Amalan Nilai-Nilai Murni. Prosiding: Seminar Penyelidikan Kebangsaan 2014

11. Yazilmiwati Yaacob, Ilhaamie Abdul Ghani Azmi, (2012). Entrepreneurs' Personality from Islamic Perspective: A Study of Successful Muslim Entrepreneurs in Malaysia. Doi: 10.7763/IPEDR. 2012. V46. 16.

12. Shuhairimi Abdullah. (2011). Aplikasi Nilai- Nilai Murni Dalam Kalangan Usahawan ke Arah Pembangunan Usahawan Muslim Yang Holistik. Kertas Kerja Seminar Keusahawanan Islam II Peringkat Kebangsaan.

13. Ab. Aziz Yusof, Pengenalan kepada Usahawan dan Keusahawanan (Kuala Lumpur: Scholar Mind Publishing, 2010)

14. N.K. Denzin, Y.S. Lincoln, Y. S. (Eds.). (2003). Collecting and Interpreting Qualitative Materials. ( $2^{\text {nd }}$ Ed). Thousand Oaks, CA: Sage.

15. S. Habibollah. A. Hamed, N. Davoud, International Journal of Business and Management 5(7), (2010)
16. Al-Quran al-Karim Terjemahan (2012). Kajang, Selangor.

17. M.A. Abdullah, A. Hoetoro, International Journal of Management and Business Research 1(1), 35-46 (2011)

18. Adnan Alias, Mohamed Dahlan Ibrahim, Keusahawahanan Islam (Petaling Jaya: Prentice Hall, 2002)

19. Global Entrepreneurship Monitor, "Report on Social Entreprenurship 2009” (Report) (London, United Kingdom, 2009)

20. H. Jiao, Social Enterprise Journal 7(2), 130149 doi:10.1108/17508611111156600

21. Mohd. Fadzillah Kamsah, Muhammad Zakaria, Langkah Bijak Usahawan Terbilang (Kuala Lumpur: Telaga Biru Sdn Bhd., 2008)

22. Muhammad Ali Hashim, Khalifah Ganti Superman (Kuala Lumpur: Utusan Publications \& Distributors Sdn Bhd., 2013)

23. Mohamad Mustapha, Keusahawanan Islam (Petaling Jaya: Prentice Hall, 2002)

24. P.J. Murphy, S.M. Coombes, Journal of Business Ethics 87, 325-336 (2009)

25. A. Nicholls, Social Entrepreneurship: New Models of Sustainable Social Change (Oxford University Press, Oxford, 2008)

26. Radin Siti Aishah, Zaidatol Akmaliah, "Keusahawanan Sosial Dari Perspektif Islam". In Proceeding of the International Conference on Research in Ethics Education 2013. Istanbul Turki (2013)

27. E. Shaw, (2011) Toward A Theory of Entrepreneurship: The Significance and Meaning of Performance and the Emotion Management of Entrepreneurs A Thesis submitted for the Degree of Doctor of Philosophy By Elizabeth Shaw Brunel School of Business and Management Brunel Unive. Brunel University.

28. Shuhairimi Abdullah, Journal of Islamic Human Advanced Research 3, 322-345 (2013)

29. Suhaimi Mhd Sarif, Abdullah Sarwar, Yusof Ismail, Middle East Journal of Scientific Research 14 (11), 1463-1470 (2013)

30. C.S. Teresa, L.N. Patricia, Journal of Research in Marketing and Entrepreneurship 11(1), 49-65 (2009)

31. J. Weerawardena, G.S. Mort, Journal of World Business 41(1), 21-35 (2006)

32. S.A. Zahra, H.V. Rawhouser, N. Bhawe, D.O. Neubaum, J.C. Hayton, Strategic Entrepreneurship Journal 2(2), 117-31 (2008) 